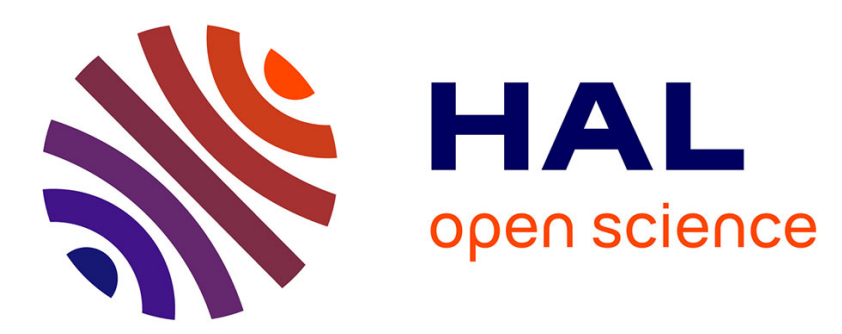

\title{
How do people behave during flash floods and why? Lessons for the prediction of the human vulnerability dynamics in short-fuse weather events
}

Javed Ali, Isabelle Ruin

\section{- To cite this version:}

Javed Ali, Isabelle Ruin. How do people behave during flash floods and why? Lessons for the prediction of the human vulnerability dynamics in short-fuse weather events. EGU General Assembly 2019, Apr 2019, Vienna, Austria. hal-02123257

\section{HAL Id: hal-02123257 \\ https://hal.science/hal-02123257}

Submitted on 7 May 2019

HAL is a multi-disciplinary open access archive for the deposit and dissemination of scientific research documents, whether they are published or not. The documents may come from teaching and research institutions in France or abroad, or from public or private research centers.
L'archive ouverte pluridisciplinaire HAL, est destinée au dépôt et à la diffusion de documents scientifiques de niveau recherche, publiés ou non, émanant des établissements d'enseignement et de recherche français ou étrangers, des laboratoires publics ou privés. 


\section{Introduction}

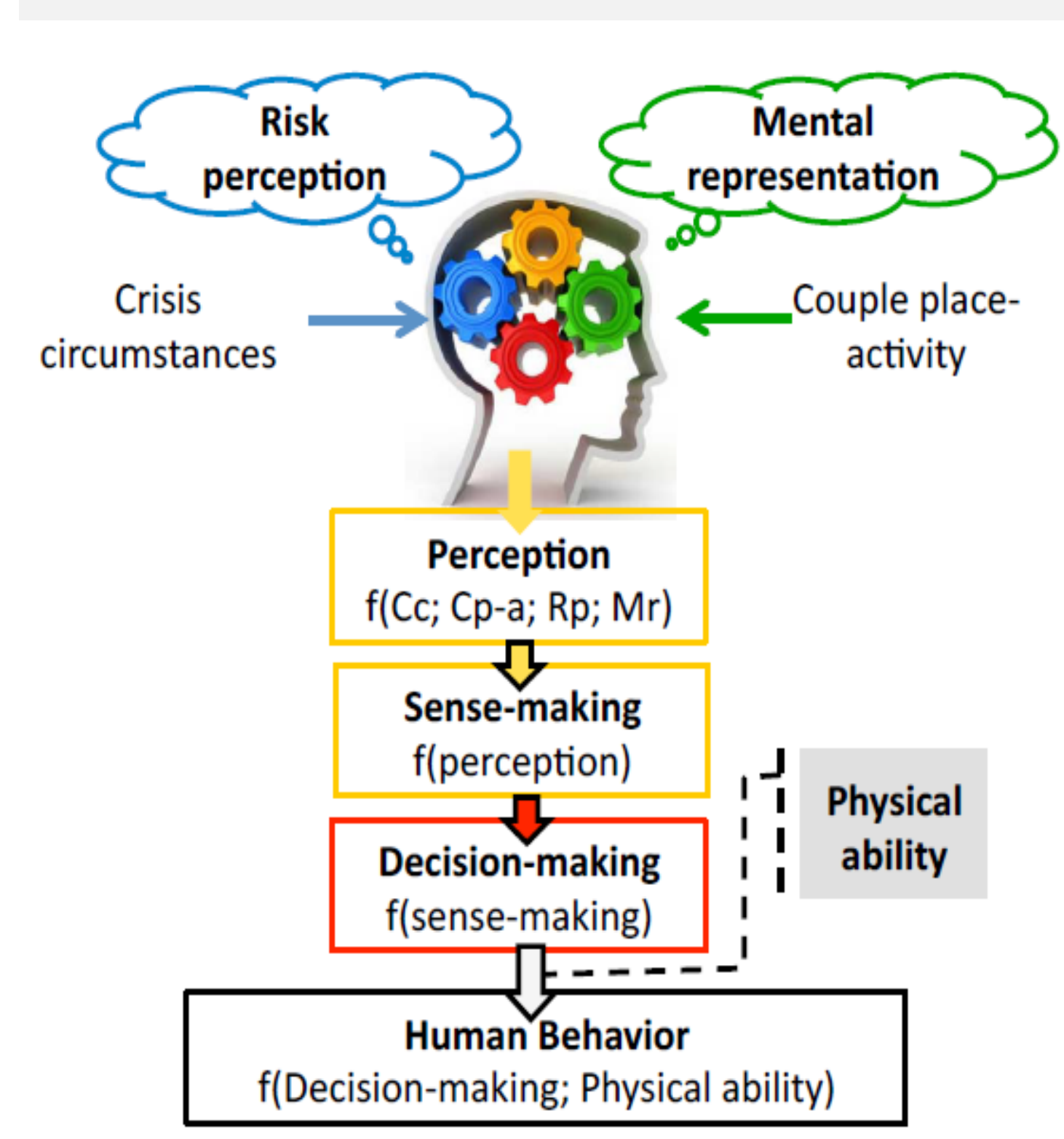

\begin{tabular}{c} 
Hearreceive \\
warning \\
Understand \\
Believe \\
Tersonalize \\
\hline Decide to act \\
\hline Tappropriate
\end{tabular}

- The characteristics of the hazard, the warning information characteristics, the situational and personal characteristics of the receiver and the socio-cultural contex are strong determinants of the public behavioural response.

In fast-moving events like flash-floods, the amount of time available to detect the threat and respond to it is so limited that protective actions often consist in dealing with contingent situations triggered by the irruption of dangerous circumstances in irruption of dangerous circumstances in
the middle of daily life activities and the middle of daily life activities and
routines (Ruin et al., 2008, 2009; Terti et al., 2015).

\section{Take approp
action}

4. Perception of the hydro-meteorological events and their severity

4.1 How do people perceive the floods?

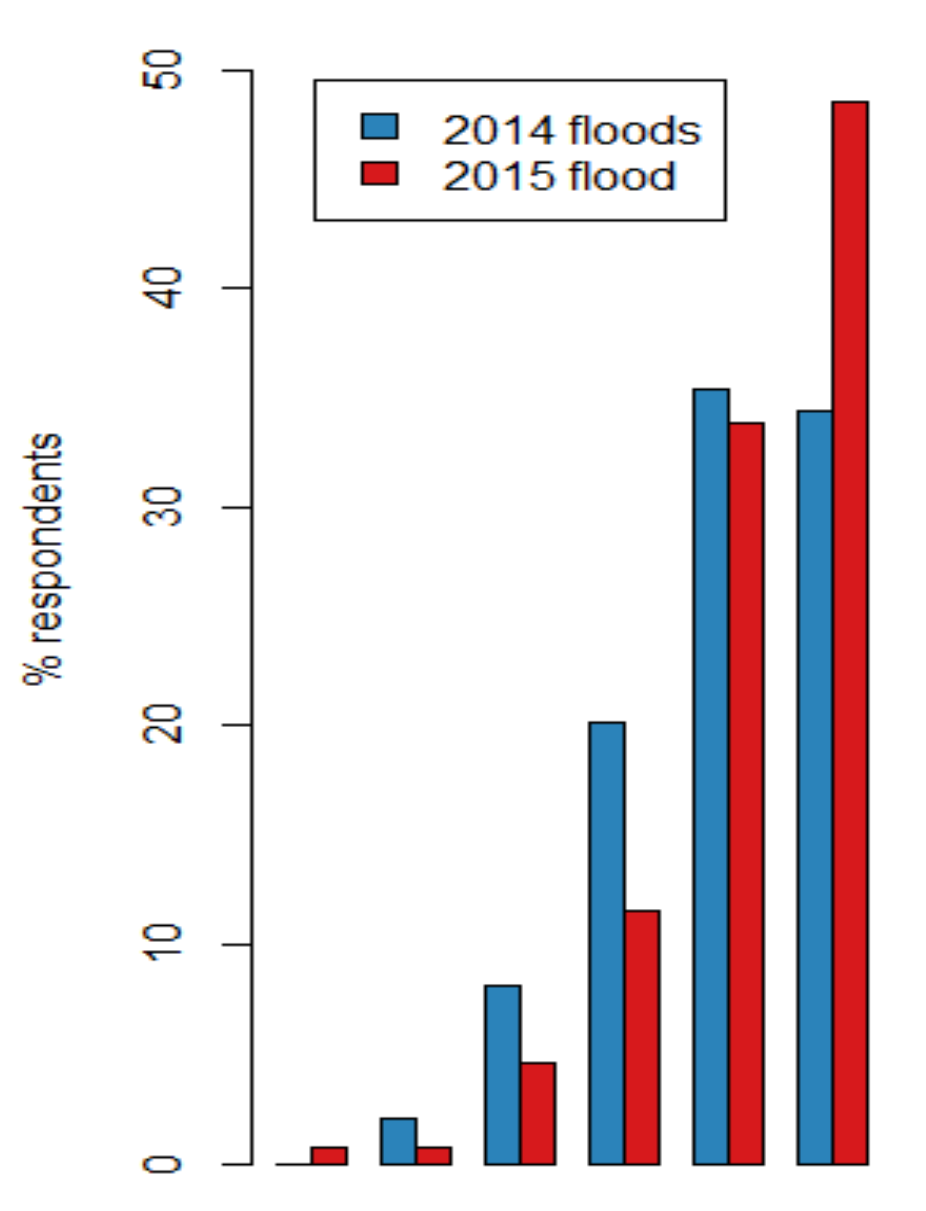

\subsection{Risk perception}

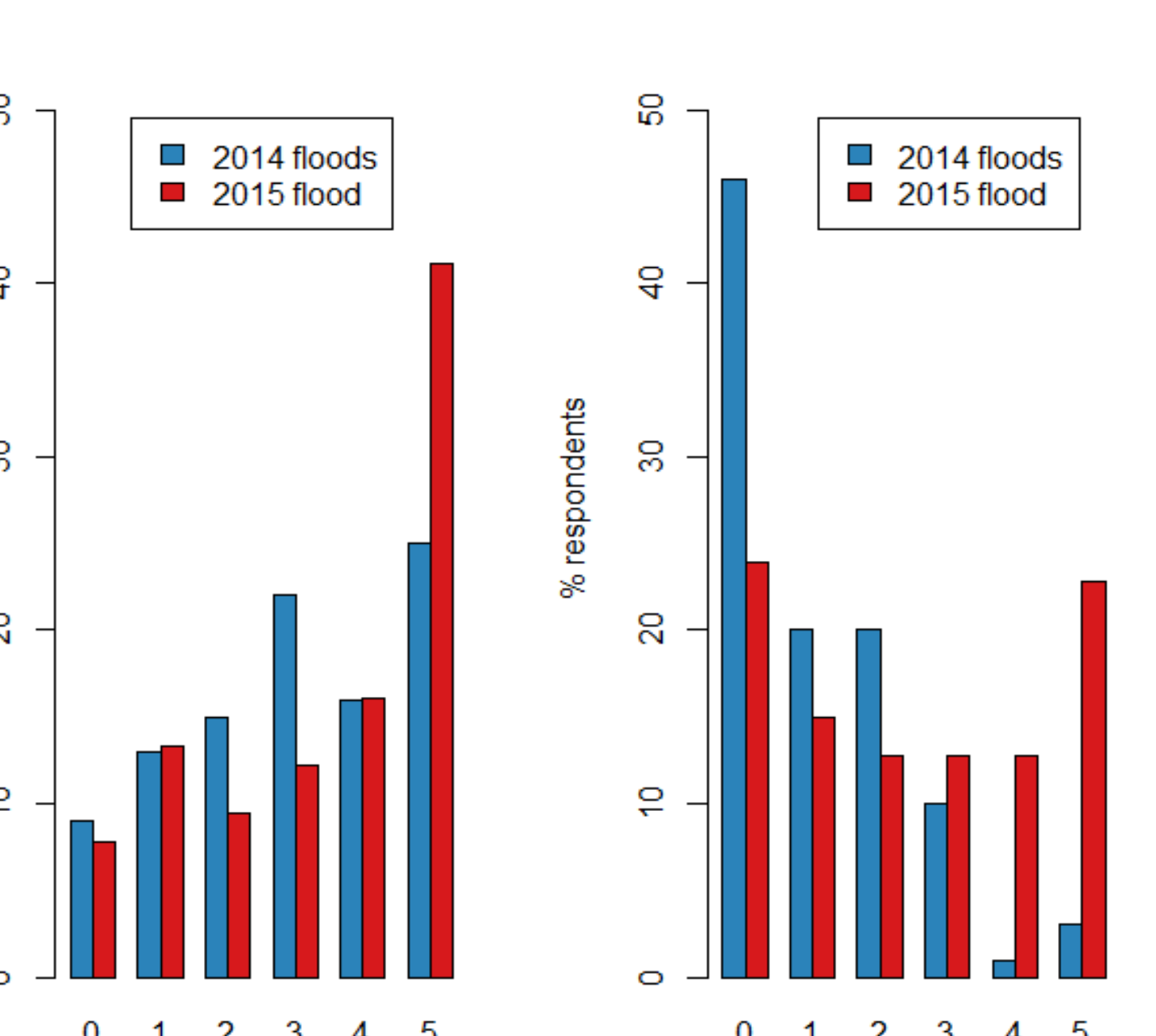

- Understanding how people actually detect potentialy dangerous circumstances and manage to timely adapt their routine to cope with the speed of the hazard evolution remains a challenge.

Based on insights from post event interviews, online surveys were used to quantitatively document behavioural responses associated with 3 catastrophic flash flood events that happened in southern France in 2014 and 2015.

A multivariate statistical analysis among different variables that define the social structure, and different subcategories that characterize people's behavior was carried out in order to investigate the linkage between these two concepts.

\section{Methodology}

\section{Data Collection}

Victims of two flash floods in 2014 and 2015 were selected in this study: one near Montpellier (Hérault department) on 30th September 2014 and another one near Nîmes (Gard department) on 10th October 2015. Online questionnaire surveys were used to collect the data about flash surveys were used to collect the data about flash
floods and social behaviors. 250 people answered the online questionnaire. The rainfall data associated to questionnaire responses were obtained from reanalysis data that combine radar and rain gauges observations data. The rainfal data was calculated at the location where the respondents were at the time of the event.

\begin{tabular}{|c|c|c|c|}
\hline Event & Montpellier-Nice-2014 & & Cammes-Nice-2015 \\
\hline Place & $\begin{array}{l}\text { Herault department } \\
\text { (Monpellier) }\end{array}$ & \begin{tabular}{|l} 
Gard department \\
Nines)
\end{tabular} & $\begin{array}{l}\text { Var +Appes-Maritimes departmentsts } \\
\text { (between Cannes and Nice) }\end{array}$ \\
\hline Date & 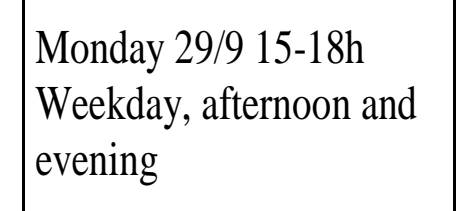 & 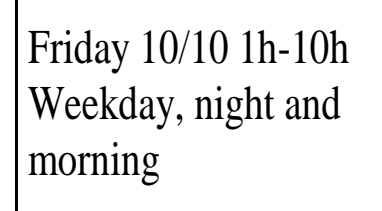 & 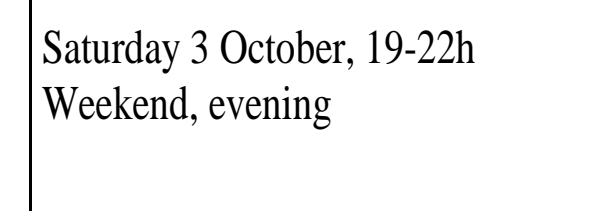 \\
\hline $\begin{array}{l}\text { Max cumulated rainlh } \\
(\mathrm{mm})\end{array}$ & 129 & 92 & 146 \\
\hline $\begin{array}{l}\text { Max cumulated rain 24h } \\
(\mathrm{mm})\end{array}$ & 352 & 426 & 215 \\
\hline Météo-France warning & Red & Red & Orange \\
\hline Impact & No death & No deaath & 20 deaths \\
\hline Number of valid answers & 100 & & 180 \\
\hline Link broadcast & Meteorological websites & & $\begin{array}{l}\text { Professional networks + } \\
\text { Meterorological websites }\end{array}$ \\
\hline $\begin{array}{l}\text { Main characteristics of the } \\
\text { sample }\end{array}$ & $\begin{array}{l}\text { Age 20-30 years (average: } \\
\text { Mostly men }\end{array}$ & & 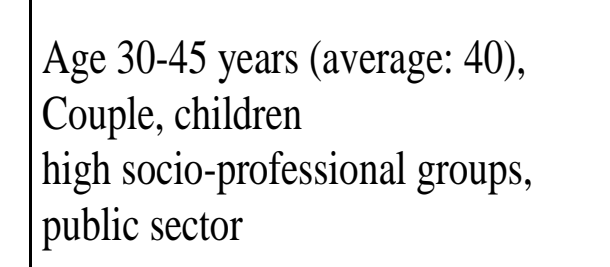 \\
\hline
\end{tabular}

4.3 How do people change their travel plans and activities during flash floods?

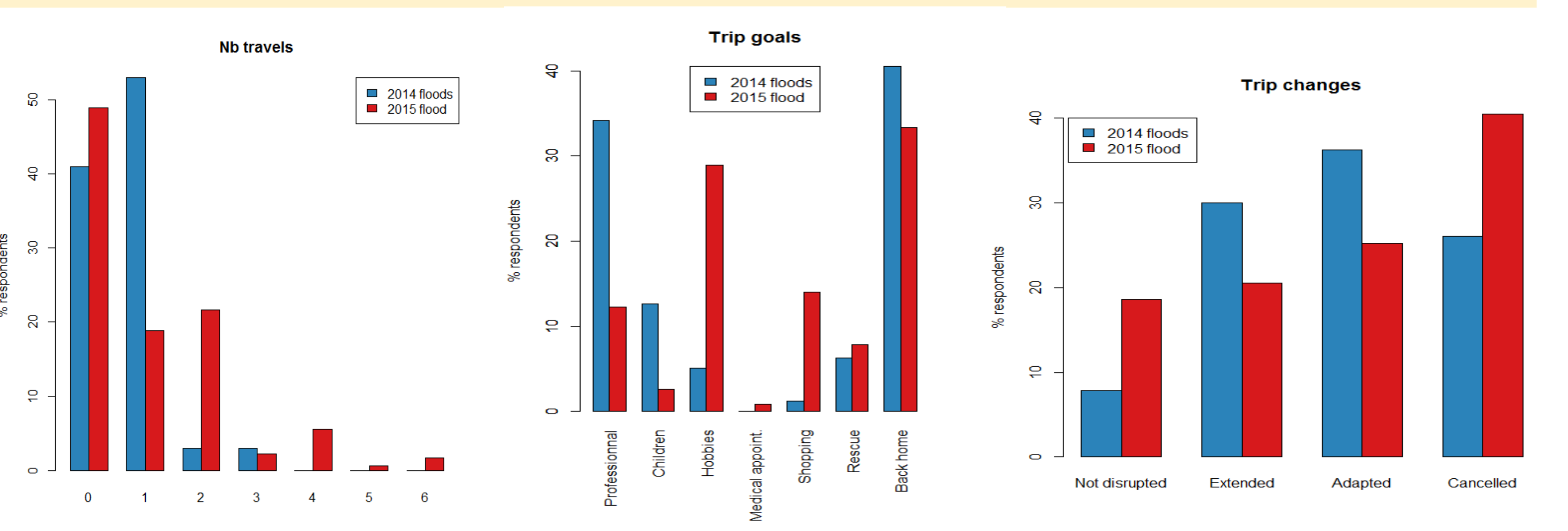

Bivariate analysis of the 2015 event

1. How does the rain change perceptions and behavior of people?
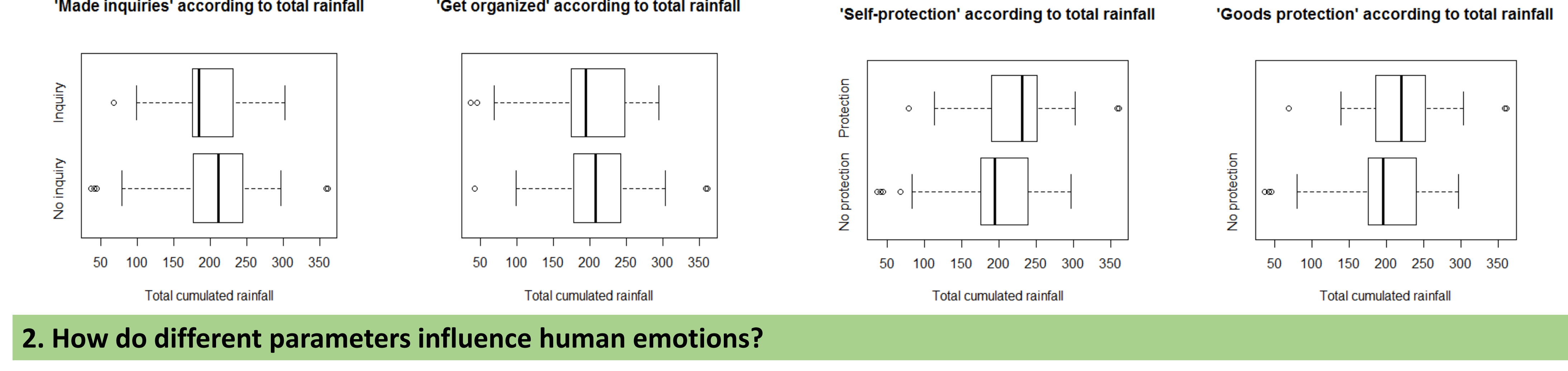

\section{Social Variables}

Estimation of detected damage levels for each respondent by adding all the declared types which have been weighted according to their seriousness:

Score of damages type

$=$ River flood + Road flood $\times 2+$ Electricity cuts $\times 3+$ Building flood $\times 4+$ School closures $\times 5+$ rescues $\times 6+$ Corporal damages $\times 7$

Estimation of general seriousness by taking the weighted most serious type

Max of damages types

$=\max ($ River flood, Road flood $\times 2$, Electricity cuts $\times 3$, Building flood $\times 4$, School closures $\times 5$, rescues $\times 6$, Corporal damages $\times 7$ )

$$
\text { Score of trip changes }=\text { Extend }+ \text { Adapt } \times 2+\text { Cancel } \times 6
$$
Max of trip changes $=\max ($ Extend, Adapt $\times 2$, Cancel $\times 6)$

\section{Estimation of activity change levels :}

Score of activity changes

$=$ Inquiry + Organize $\times 2+$ Protect goods $\times 6+$ Protect myself $\times 8+$ Rescue others $\times 8$

Maximum of activity changes

$=$ max (Inquiry, Organize $\times 2$, Protect goods $\times 6$, SProtect myself $\times 8$, Rescue others $\times 8$ )

\section{Results}

\section{Comparison between 2014 and 2015 events}

Ratio between individual (respondent) cumulated rainfall and maximum cumulated rainfall of the event was used to evaluate the difference of rainfall severity experienced by each respondent depending on thei location at the time of the event. Respondents related to the Nice-Cannes event are the ones who were exposed to the most severe rainfall circumstances followed by the Montpellier respondents

\section{Social profile}

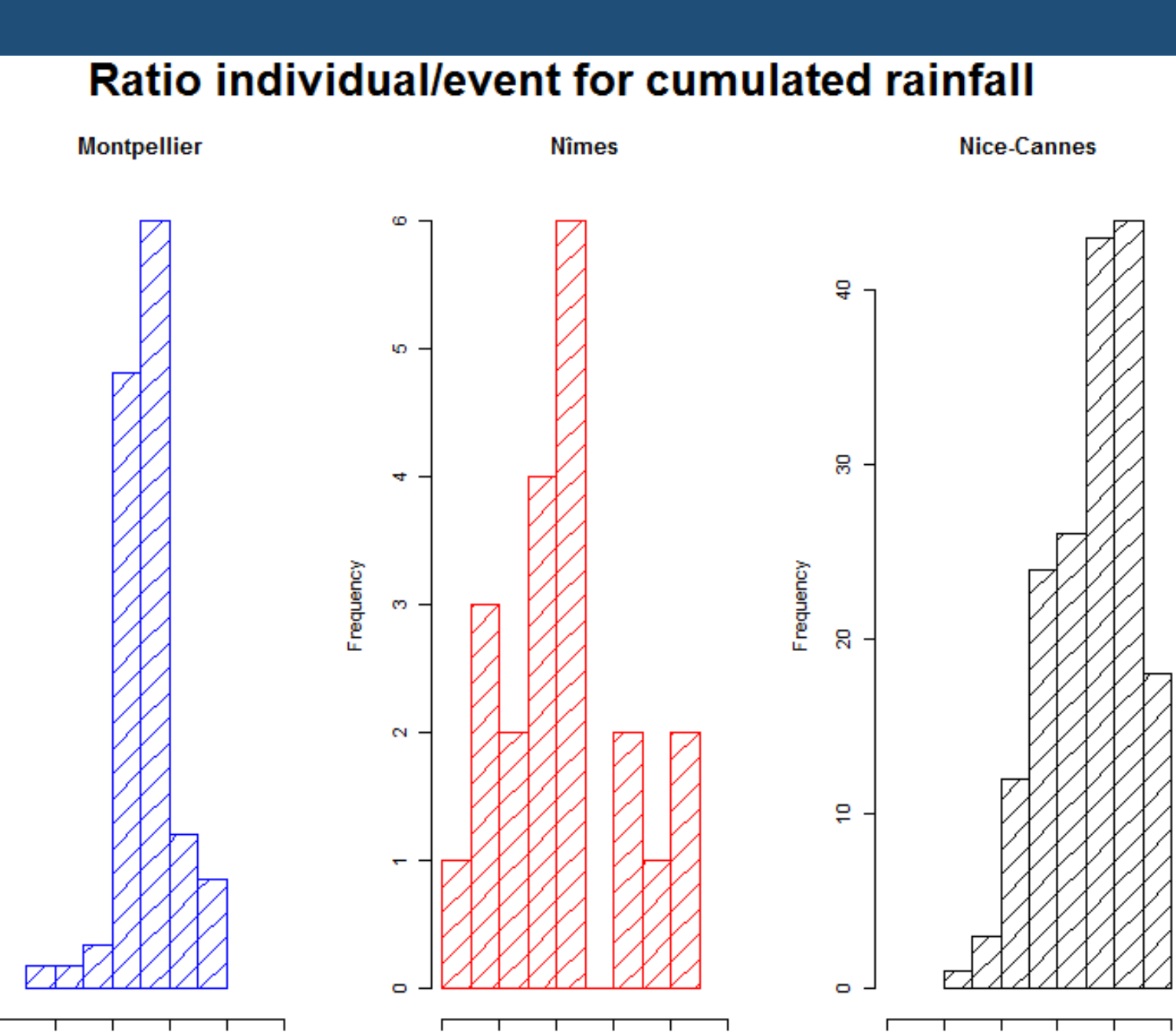

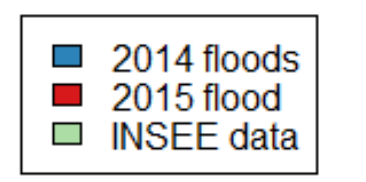

\section{Damages}
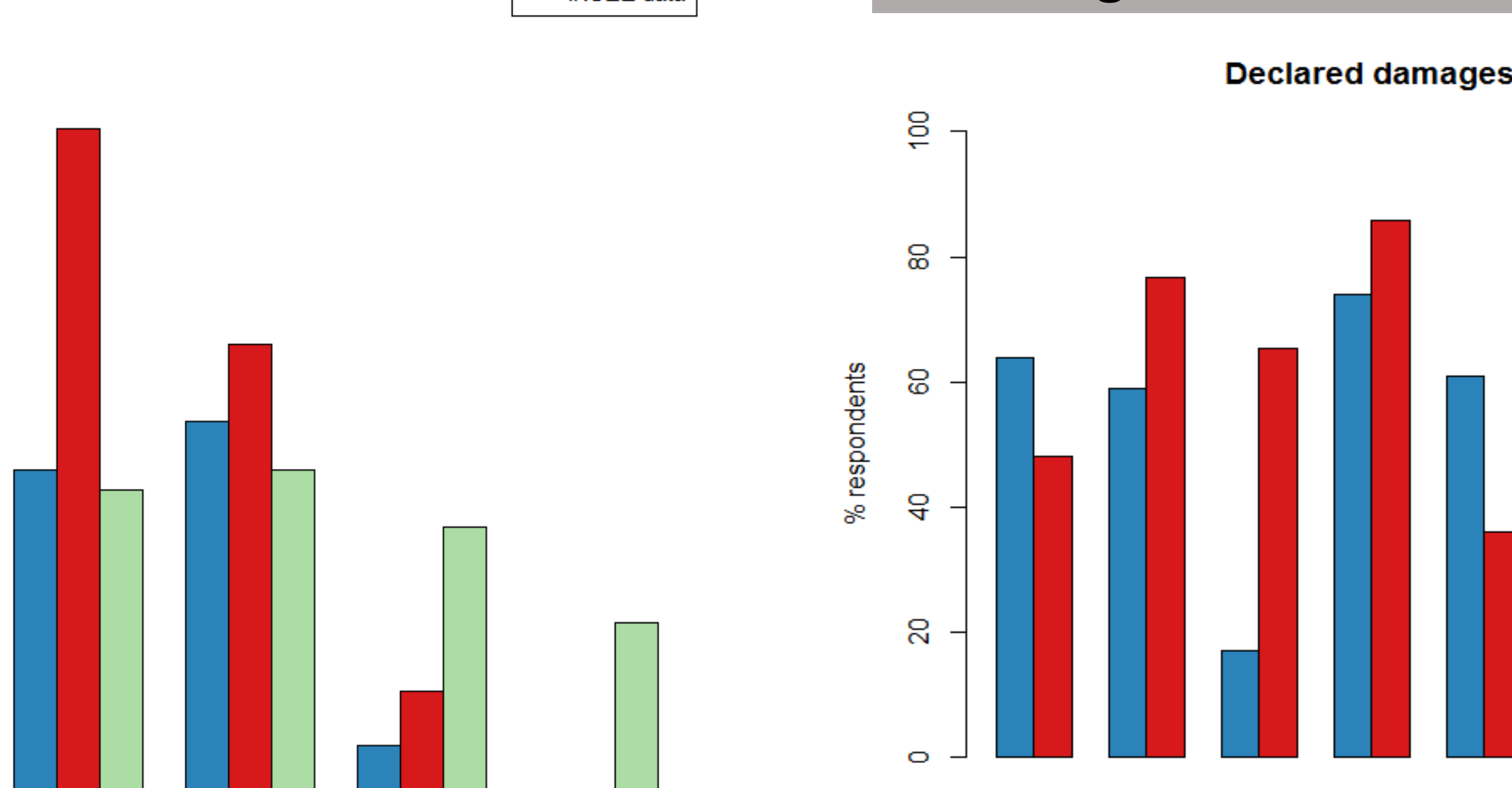
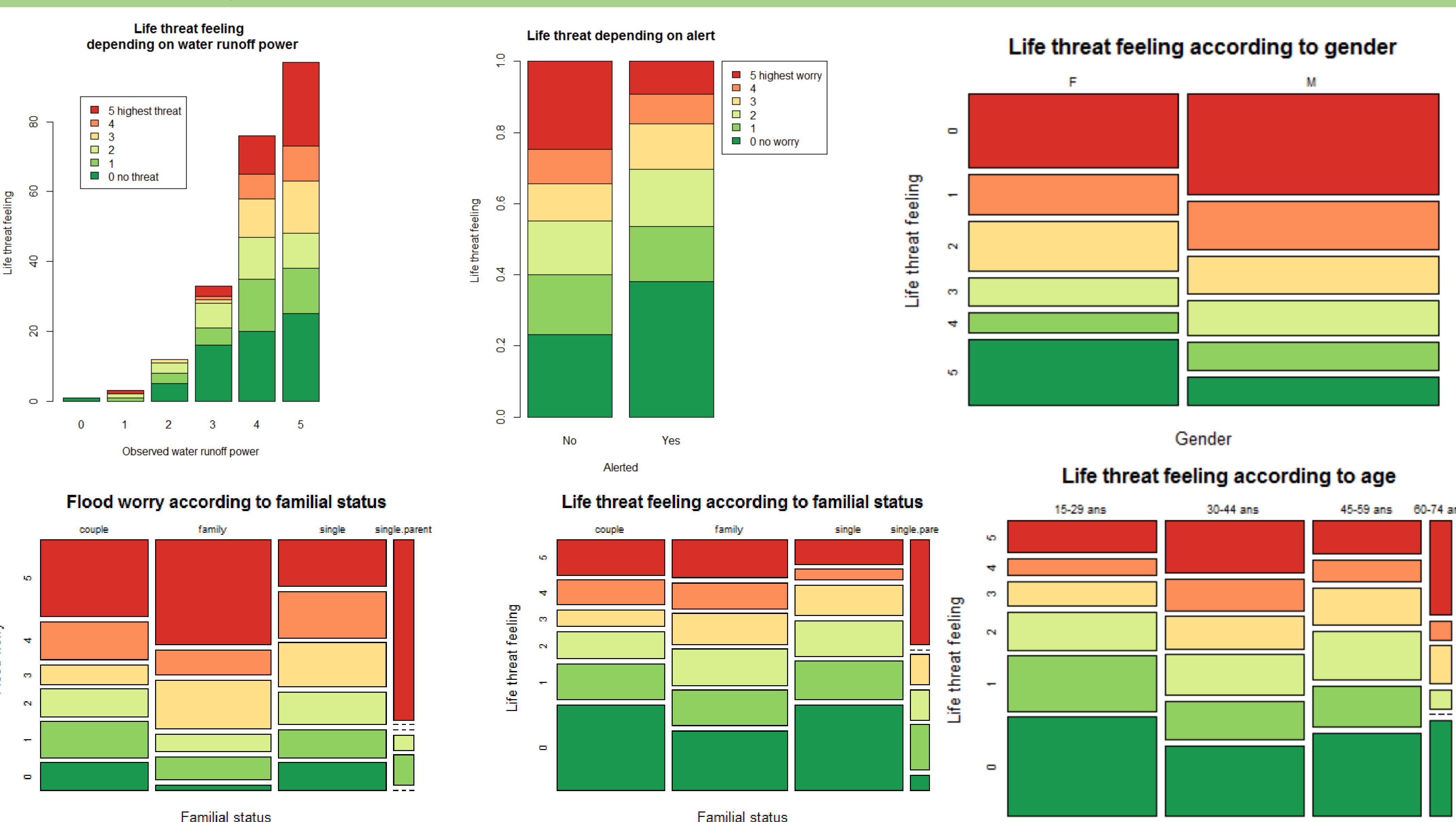

Flood worry according to ag

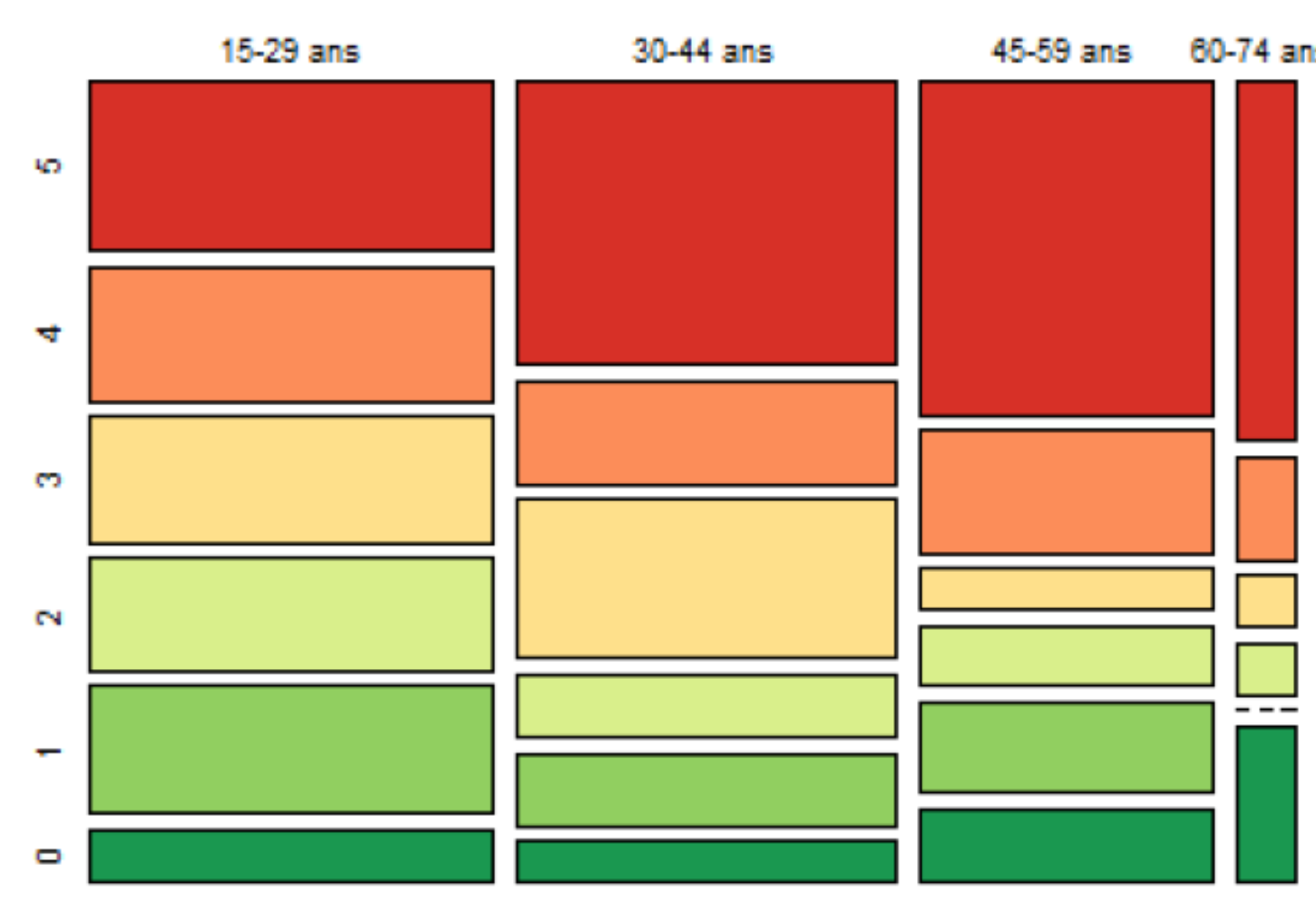

Proportion of respondents having cancelled trips

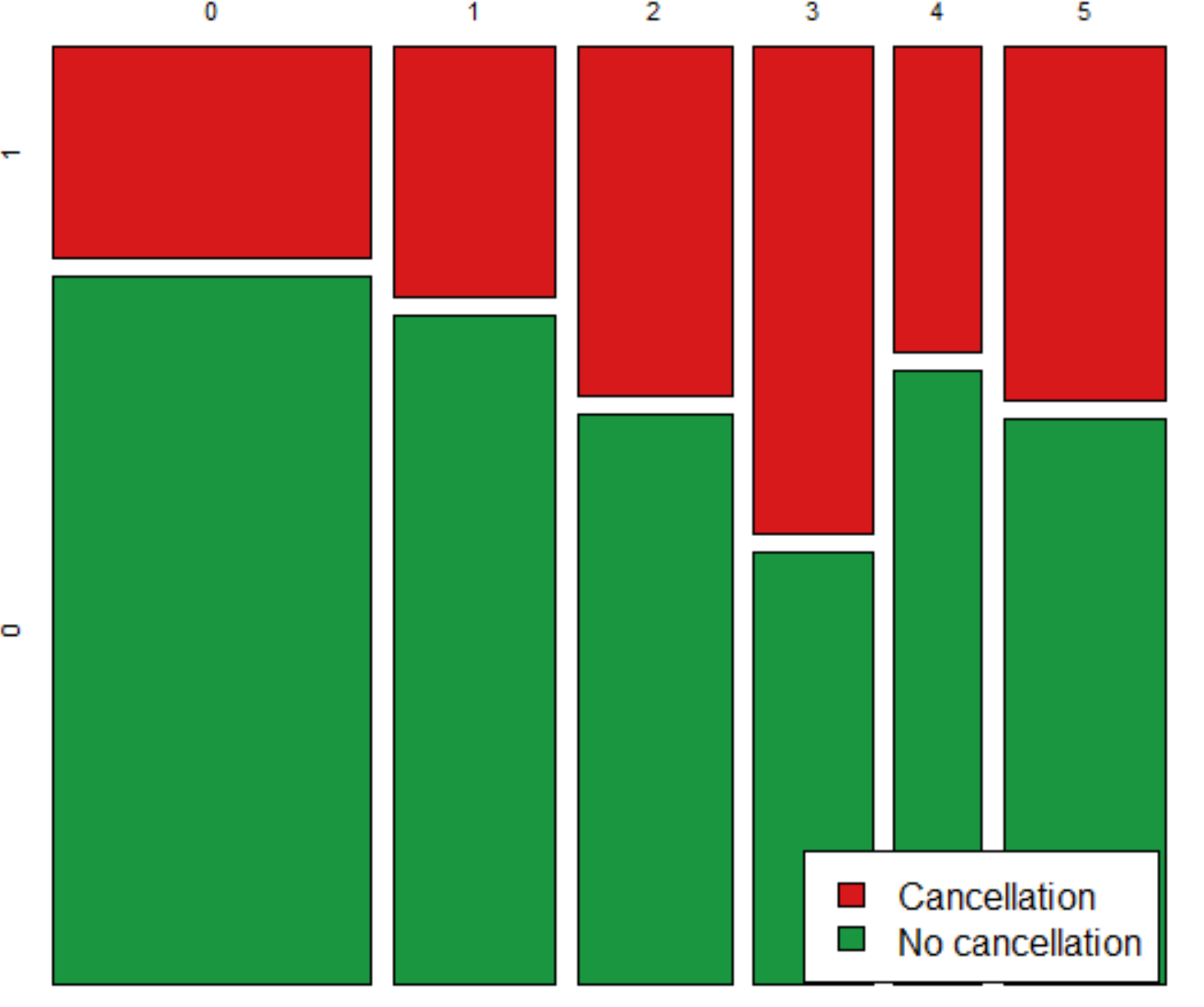

Level of threat Cancellation
No cancellation
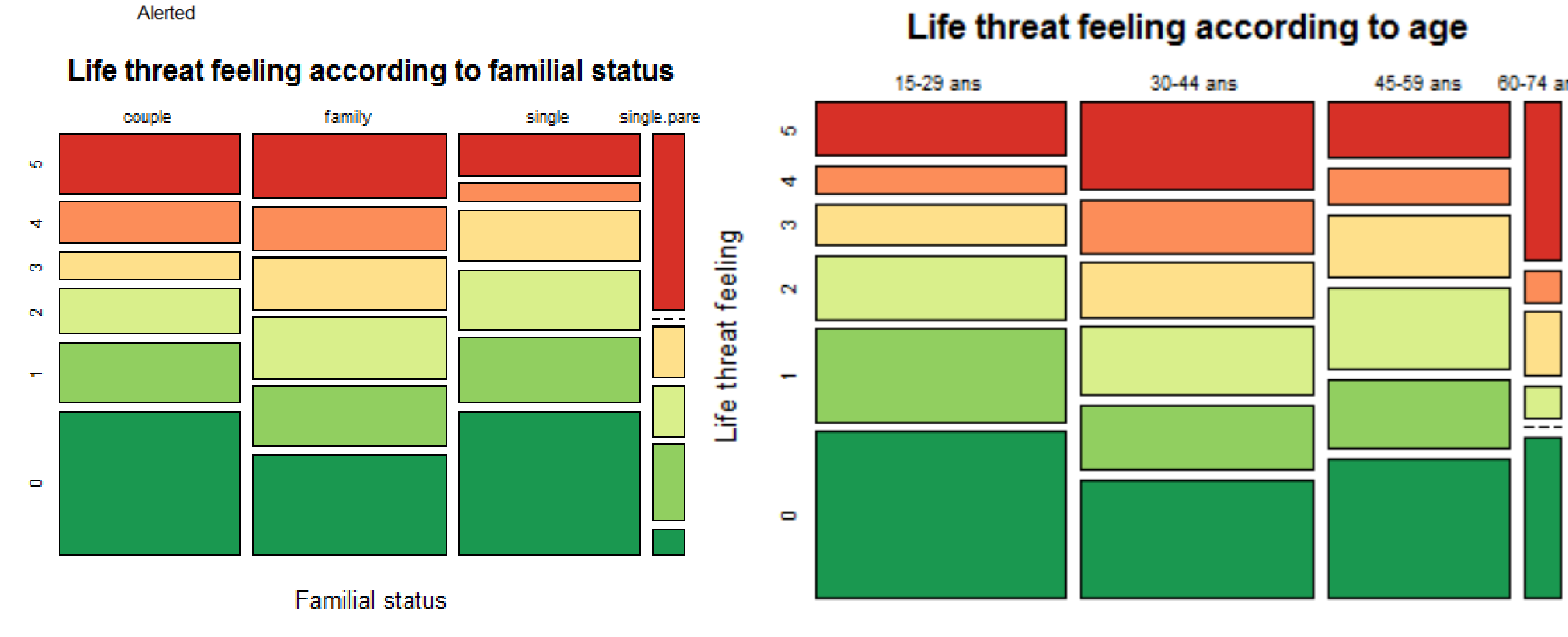

3. Protection actions and adaptation behaviors during flash flood
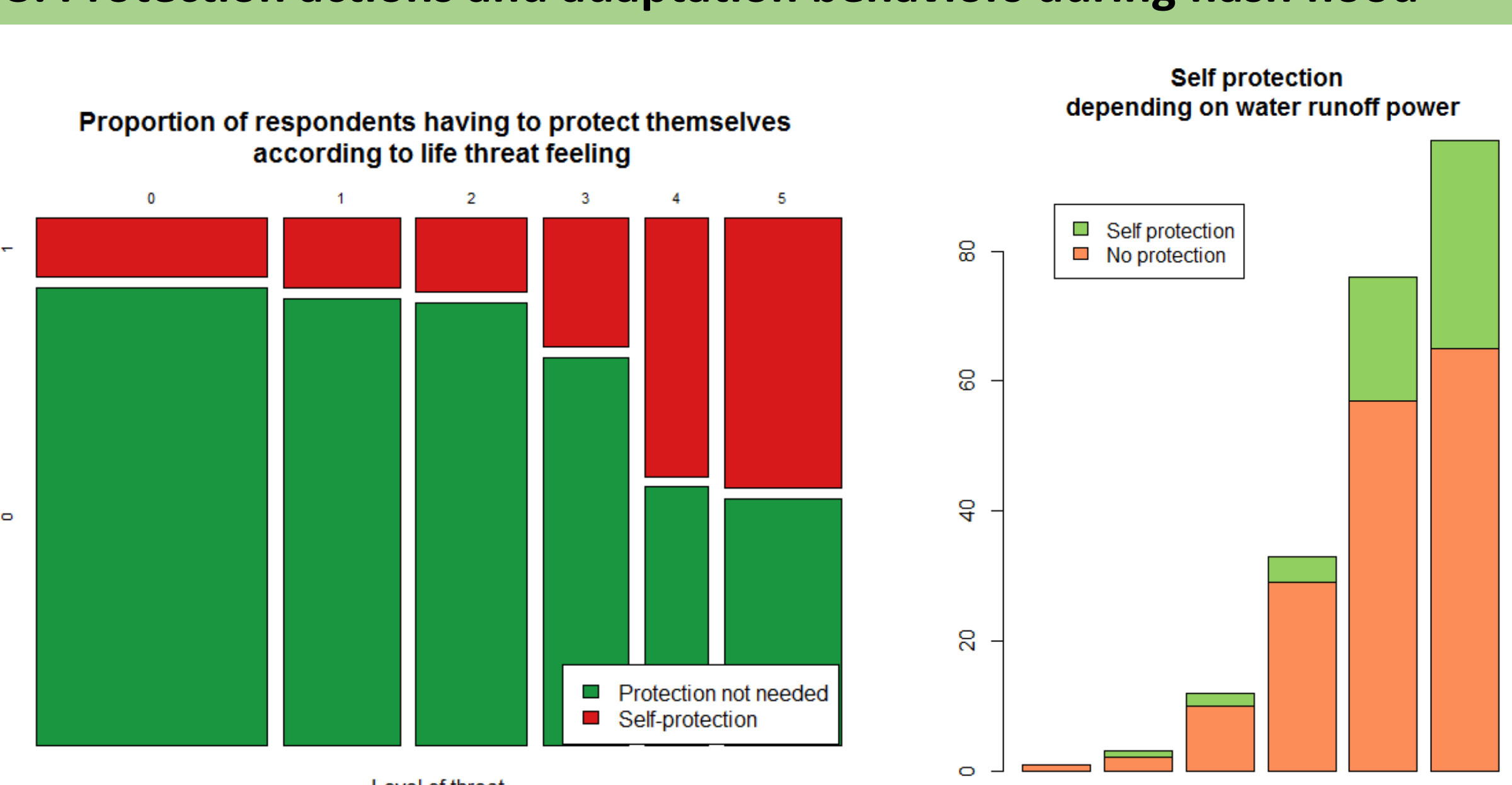

\section{Conclusion}

- The coupled analysis of responses to the surveys with hydrometeorological parameters allows to better understand the link between the event magnitude and self-protective behaviours in the context of short-fuse weather events as flash floods. Knowledge gained from such an integrated approach is necessary for drawing lessons for the development of coupled human-natural system modeling and the prediction of the human vulnerability dynamics in short-fuse weather events.

- Flash floods affect every social system differently according to its characteristics. People behave and adapt differently in a dangerous situation depending how they perceive risk or what they are doing at that the. The time and space distribution of their daily routine influence the overall human behaviour during a flooding event. 